\title{
Purpura fulminans caused by meningococcemia in an infant
}

\author{
Asad Abbas, Athar Abdul Mujeeb
}

Department of Paediatrics, Jawaharlal Nehru Medical College, Aligarh, Uttar Pradesh, India

\section{Correspondence to}

Dr Asad Abbas, syedabbas.asad@gmail.com
To cite: Abbas $A$ Mujeeb AA. BMJ Case Rep Published online: [please include Day Month Year] doi:10.1136/bcr-2013200265

\section{DESCRIPTION}

A 6-month-old infant presented with a 2-day history of fever, irritability and rashes. On examination, she was febrile, hypotensive and had a purpuric rash covering the face, trunk and extremities along with symmetrical black discolouration of fingers and toes of all limbs (figure 1). Investigations revealed leukocytosis, thrombocytopaenia and a prolonged prothrombin time; lumbar puncture was normal. Scrapings from the rash showed Gram-negative cocci in pairs. The child was not immunised against any strain of meningococcus.

She was treated with intravenous fluids, inotropes, ceftrixone and hydrocortisone. Her blood culture showed growth of Neisseria meningitidis sensitive to ceftriaxone and flouroquinolones. The patient became stable after 3 days of treatment and fever subsided. However, some of the skin lesions

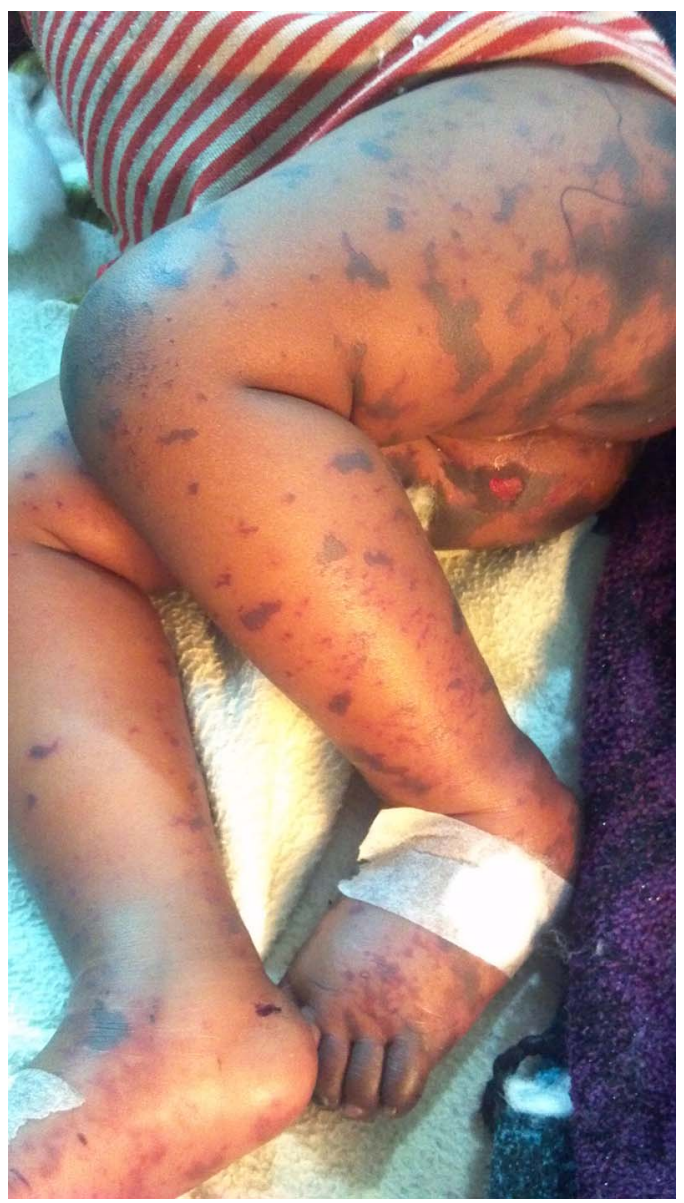

Figure 1 Purpuric rash involving the legs bilaterally with areas of sloughed off skin.

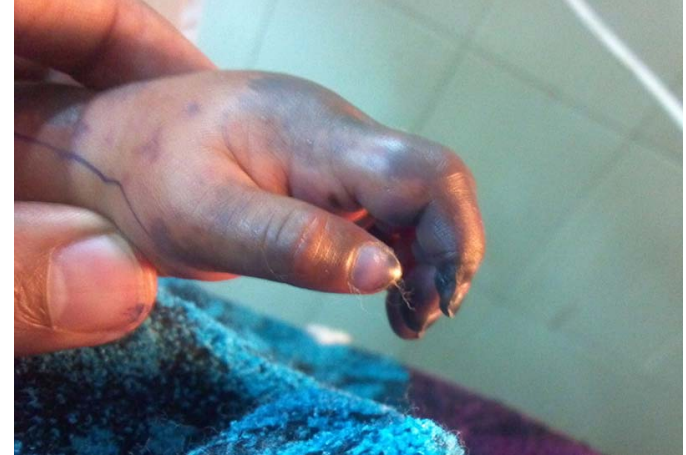

Figure 2 Gangrene involving the fingers.

sloughed off leaving raw exposed skin; the discolouration of fingers progressed to gangrene (figure 2) and eventually auto amputation of three fingers and two toes occurred.

Acute infectious purpura fulminans occurs in the setting of overwhelming sepsis caused commonly by meningococcus and Staphylococcus aureus. The primary features of this syndrome are large purpuric skin lesions, fever, hypotension and disseminated intravascular coagulation. ${ }^{1}$ Management includes antibiotic therapy as well as supportive measures that include aggressive fluid resuscitation, inotropic support and replacement of deficient blood components. Protein $\mathrm{C}$ can be given if deficient, however, its use may increase the risk of intracranial haemorrhage in patients with meningitis. ${ }^{2}$ Early use of heparin and intravenous immunoglobulins has also shown to be beneficial in some cases. $^{3}$

\section{Learning points}

- Purpura fulminans is a rare but serious complication of meningococcemia.

- Early diagnosis and aggressive management is needed to prevent serious long-term sequelae.

- Use of protein C may increase the risk of intracranial haemorrhage.

Contributors AA was the paediatrician responsible for the care of the patient and wrote the manuscript. AAM collected the images and critically reveiwed the manuscript.

Competing interests None.

Patient consent Obtained.

Provenance and peer review Not commissioned; externally peer reviewed. 


\section{REFERENCES}

1 Chalmers $\mathrm{E}$, Cooper $\mathrm{P}$, Forman $\mathrm{K}$, et al. Purpura fulminans: recognition, diagnosis and management. Arch Dis Child 2011;96:1066-71.

2 Smith OP, White B. Infectious purpura fulminans: caution needed in the use of protein C. Br J Haematol 1999;106:253-4.
3 Kaul R, McGeer A, Norrby-Teglund A, et al. Intravenous immunoglobulin therapy for streptococcal toxic shock syndrome-a comparative observational study. The Canadian Streptococcal Study Group. Clin Infect Dis 1999;28:800-7.

Copyright 2013 BMJ Publishing Group. All rights reserved. For permission to reuse any of this content visit http://group.bmj.com/group/rights-licensing/permissions.

BMJ Case Report Fellows may re-use this article for personal use and teaching without any further permission.

Become a Fellow of BMJ Case Reports today and you can:

- Submit as many cases as you like

- Enjoy fast sympathetic peer review and rapid publication of accepted articles

- Access all the published articles

- Re-use any of the published material for personal use and teaching without further permission

For information on Institutional Fellowships contact consortiasales@bmjgroup.com

Visit casereports.bmj.com for more articles like this and to become a Fellow 